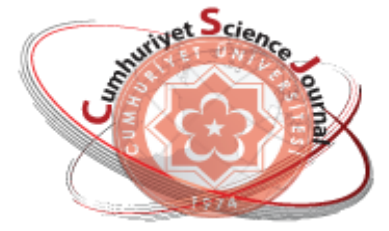

e-ISSN: $2587-246 X$

ISSN: $2587-2680$

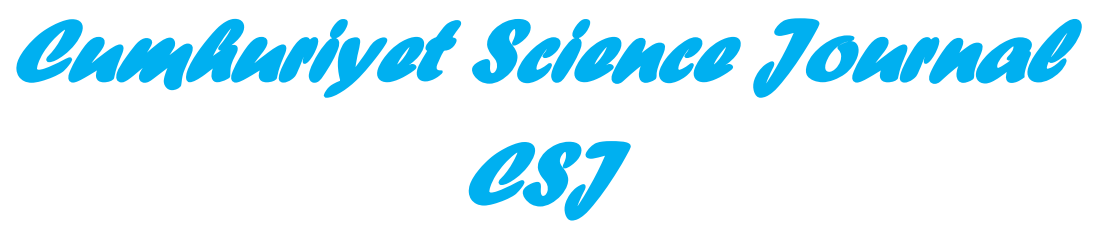

Cumhuriyet Sci. J., Vol.39-2(2018) 399-405

\title{
Effects of (Mo/W) Co-Doping on Bulk BSCCO Superconductor
}

\author{
Asll Asiye AGIL ${ }^{1}$, Hakan GUNDOGMUS ${ }^{1^{*}}$, Sukru KARATAS ${ }^{2}$ \\ ${ }^{1}$ Hakkari University, Faculty of Engineering, Hakkari, TURKEY \\ ${ }^{2}$ Kahramanmaraş Sütçü Imam University, Faculty of Engineering, Kahramanmaraş, TURKEY \\ Received: 22.01.2018; Accepted: 11.05.2018 \\ http://dx.doi.org/10.17776/csj.382286
}

\begin{abstract}
The effect of Mo substituting and $\mathrm{W}$ doping on $(\mathrm{BiPb})_{2} \mathrm{~W}_{\mathrm{x}} \mathrm{Sr}_{2} \mathrm{Ca}_{3} \mathrm{Cu}_{4-\mathrm{y}} \mathrm{Mo}_{\mathrm{y}} \mathrm{O}_{12+\&}$ system where $\mathrm{x}=0$, $\mathrm{y}=0 ; \mathrm{x}=0.1, \mathrm{y}=0.0,0.03,0.06,0.09$ and 0.12 have been investigated. The superconducting samples prepared by using conventional solid state reaction method. The calcination and sintering temperatures were obtained by using differential thermal analysis technique (TGA). In order to investigate crystal structure properties and determine the phase determination, X-ray powder diffraction (XRD) measurements were performed. The XRD data showed that the Bi-(2223) phase transforms into the Bi-(2212) phase with increasing Mo substituting for $\mathrm{Cu}$. The morphology properties of the samples determined with the scanning electron microscopy (SEM) measurements. The effects of Mo and W substituted on BSCCO system; we have also performed electrical resistivity (R-T) in order to get critical temperatures. From electrical resistivity critical temperature and transition temperature width were both increased with the increasing of Mo content. The alternative current susceptibility measurement (AC) was performed to obtain critical transition temperature and study magnetic properties of the samples.
\end{abstract}

Keywords: Differential thermal analysis, physical properties, solid state reaction.

\section{BSCCO Süper İletkeninde (Mo / W) Eş-Katkılamanın Etkileri}

Özet: $\mathrm{Bu}$ çalışmada, Mo ve W elementlerinin ortak katkılamasının (BiPb)2WxSr2Ca3Cu4-yMoyO12+\& süper iletkeni üzerindeki $\mathrm{x}=0, \mathrm{y}=0 ; \mathrm{x}=0.1, \mathrm{y}=0.0,0.03,0.06,0.09$ ve 0.12 değerleri için etkileri araştırıldı. Üretilen malzemeler için iyi bilinen geleneksel katı hal tepkime metodu kullanıldı. Kalsinasyon ve sinterleme sıcaklıkları diferansiyel termal analiz tekniği (TGA) kullanılarak elde edildi. Kristal yapı özelliklerini araştırmak ve faz belirlenmesini belirlemek için X-1şını toz kırınım (XRD) ölçümleri yapıldı. XRD verileri, Cu'nin yerini alan Mo ile birlikte Bi- (2223) fazının Bi- (2212) fazına dönüştüğünü göstermiştir. Numunelerin morfolojik özellikleri taramalı elektron mikroskobu (SEM) ölçümleri ile belirlenmiştir. BSCCO sisteminde ikame edilen Mo ve W'nin etkileri; kritik sıcaklıkları elde etmek için elektrik direnç (R-T) ölçümleri gerçekleştirdik. Elektrik direncinden kritik sıcaklık ve geçiş sıcaklığı genişliği hem Mo içeriğinin artmasıyla artmıştır. Alternatif akım duyarlılık ölçümü (AC), kritik geçiş sıcaklığı elde etmek ve numunelerin manyetik özelliklerini incelemek için gerçekleştirildi.

Anahtar Kelimeler: Diferansiyel termal analiz, fiziksel özellikler, katı hal tepkime metodu.

\section{INTRODUCTION}

Bi-based superconductor systems can be formulated by $\mathrm{Bi}_{2} \mathrm{Sr}_{2} \mathrm{Ca}_{n-1} \mathrm{Cu}_{n} \mathrm{O}_{x}$ (BSCCO) with $n=1,2,3$ and illustrated Bi-2201, Bi2212 and Bi-2232, respectively. Bi-2212 and Bi-2232 have important features for technologic applications [1-5].

\footnotetext{
* Corresponding author. Email address: hkngundogmus@gmail.com http://dergipark.gov.tr/csj $\quad$ C2016 Faculty of Science, Cumhuriyet University
} 
It is known that the materials produced up to this day are almost impossible to synthesize the material containing the 2223 phase alone, and that the material produced contains the 2212 phase in large proportion together with the 2223 phase [6-8]. Therefore, the synthesis of the samples with the high transition temperature 2223 phase alone is of great importance in the scientific and technological direction. As these materials are more flexible than other type II superconductors, there are applications such as wire, thin film coating, superconducting magnet making in the technology [4, 9-11].

Since the different reaction rates and mobility of $\mathrm{Bi}, \mathrm{Ca}, \mathrm{Cu}, \mathrm{Sr}$ and $\mathrm{Pb}$ cations in the $\mathrm{BSCCO}$ superconductors, it is very difficult to distribute homogeneously within the system. The reaction of more than one element with each other at high temperatures results in the formation of impurity phases which cause the phase of 2223 to decrease. The temperature range required for 2223 phase formation is very limited and depends on the stoichiometry of the material. The superconducting features of Bi-based superconductors are related to the hole concentration so lots of the studies have been made on $\mathrm{Cu}$ site [12-14]. Also substitution on $\mathrm{Ca}$ site has been studied in order to improve physical features of Bi-based superconductor. The cationic substitutions for $\mathrm{Ca}$ on $\mathrm{Bi}$-based superconductors affect the mechanical and superconducting properties due to exchange of the carrier concentration [12, 15-17].

In this study we aim to synthesize BSCCO superconducting sample, which is composed of 2223 phase or 2223 phase in the single phase. The structure of the materials analyzed by Xray diffraction method, the surface and grain formations of the material investigated by scanning electron microscope (SEM). Also electrical and magnetic measurements were performed in order to get the transition temperature (Tc) and investigated the effects of doping $\mathrm{W}$ and substituted Mo on BSCCO system.

\section{EXPERIMENTAL PROCESS}

$(\mathrm{BiPb})_{2} \mathrm{~W}_{\mathrm{x}} \mathrm{Sr}_{2} \mathrm{Ca}_{3} \mathrm{Cu}_{4-\mathrm{y}} \mathrm{Moy}_{\mathrm{y}} \mathrm{O}_{12+\&} \quad$ superconducting samples where $\mathrm{x}=0, \mathrm{y}=0 ; \mathrm{x}=0.1$, $\mathrm{y}=0.0,0.03,0.06,0.09$ and 0.12 , were prepared by the conventional solid state reaction method. Bi-based superconducting samples were prepared by using commercial $99.999 \% \mathrm{Bi}_{2} \mathrm{O}_{3}$ powder (Sigma Aldrich), 99.9\% powder $\mathrm{PbO}$ (Sigma Aldrich), 99.9\% SrO powder (Sigma Aldrich), $99.998 \% \mathrm{CaO}$ powder (Alfa Aesar) (Sigma Aldrich), 99.9\% $\quad \mathrm{WO}_{3}$ powder (Sigma Aldrich) and $99.5 \% \quad \mathrm{MoO}_{3}$ powder (Sigma Aldrich). The pure powders were carefully weighed in the stoichiometric ratio and milled for an hour in the air with agate mortar. We performed two steps of calcination; for the first calcination the milled powders were placed in the ash furnace at temperature $700{ }^{\circ} \mathrm{C}$ for 12 hours. After this heat treatment in order to get good homogenization and reduction of the particle size samples were grinding about 1 hour in the air. We put our samples in the ash furnace for second calcination at $800{ }^{\circ} \mathrm{C}$ for 12 hours. The resulting homogeneous powders were then pelletized with applying pressure about 6 tons. We put pelletized samples in a high temperature furnace at $845{ }^{\circ} \mathrm{C}$ for 120 hours in order to get superconducting phases then quenched in air to room temperature. $(\mathrm{BiPb})_{2} \mathrm{~W}_{\mathrm{x}} \mathrm{Sr}_{2} \mathrm{Ca}_{3} \mathrm{Cu}_{4-\mathrm{y}} \mathrm{Mo}_{\mathrm{y}} \mathrm{O}_{12+\&}$ superconducting samples where $\mathrm{x}=0, \mathrm{y}=0 ; \mathrm{x}=$ $0.1, \mathrm{y}=0.0,0.03,0.06,0.09$ and 0.12 , will be hereafter named as A, B, C, D, E and F respectively.

In order to obtained calcinations and sintering temperatures were performed at room temperature and $1000{ }^{\circ} \mathrm{C}$ with TG/DTA 6300 . TGA measurements were taken at ambient temperature and at a heating rate of $5{ }^{\circ} \mathrm{C} / \mathrm{min}$. Phase formation and microstructure analysis on our samples were investigated by $\mathrm{X}$-ray powder diffraction (XRD) with $\mathrm{Cu}-\mathrm{K} \alpha$ radiation by using Rigaku RadB-D MAX II powder diffractometer system. Morphological properties of the samples were carried out by a scanning electron microscope (SEM) with 
JEOL SEM 7700F instrument. The conventional four-point probe method was used for resistivity measurement. AC susceptibility measurements were performed using the "Lake Shore 7130 AC Susceptometer" system with a cooling system using closed-loop liquid helium. Magnetic measurements of the samples carried out with a VSM at temperatures of $20 \mathrm{~K}$ and an applied field of \pm 1 .

\section{RESULTS and DISCUSSION}

Differential scanning calorimeter measurements (TGA) were taken in order to arrange the appropriate heat treatment temperature range for prepared samples. Measurements were carried out between room temperature and 1000 ${ }^{\circ} \mathrm{C}$ in the air. From Fig. 1., the first weight loss obtained between 300 and $400{ }^{\circ} \mathrm{C}$ because of melting of the lead in the structure. The reason for the loss of the second weight in the curves is thought to originate from the impurities in the starting powders. This reduction would not have been observed if $100 \%$ pure starting powders had been produced under normal conditions. From these curves, the final heat treatment temperature has been determined at $845{ }^{\circ} \mathrm{C}$, which these weight losses become almost constant.

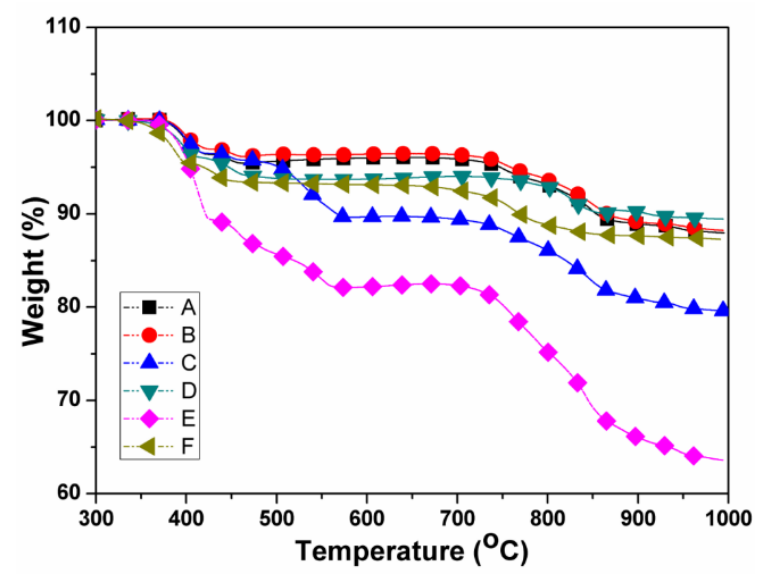

Figure 1. TGA curves of all samples.

X-ray diffraction patterns of all samples were examined by powder diffractometer and detailed information about structure formations was obtained and illustrated in Fig. 2. From this figure patterns of sample $A$ contains the tetragonal BSCCO phase and small amount of $\mathrm{Ca}_{2} \mathrm{PbO}_{4}$ impurities at $2 \theta=47.7^{\circ}$. In the case of the doped samples, the main phases are $\mathrm{Bi}-2223$ and Bi-2212 phases. The peaks of Bi-2212 are observed at $2 \theta=23.3^{\circ}, 27.6^{\circ}, 31.1^{\circ}, 41.5^{\circ}, 55.2^{\circ}$ and $56.6^{\circ}$. In addition, the $\mathrm{PbO}$ phase, which does not react with all of the doped samples, is found at $2 \theta=17.8^{\circ}$. This confirmed the first weight loss in the TGA analysis. In the superconductor samples, some impurities and the non-superconducting $\mathrm{Ca}_{2} \mathrm{PbO}_{4}$ phase was detected. The calculated lattice parameters are showed in Table 1 . by XRD patterns $(\mathrm{BiPb})_{2} \mathrm{~W}_{\mathrm{x}} \mathrm{Sr}_{2} \mathrm{Ca}_{3} \mathrm{Cu}_{4-\mathrm{y}} \mathrm{Mo}_{\mathrm{y}} \mathrm{O}_{12+\&} \quad$ superconducting samples with the Whatfor programme.

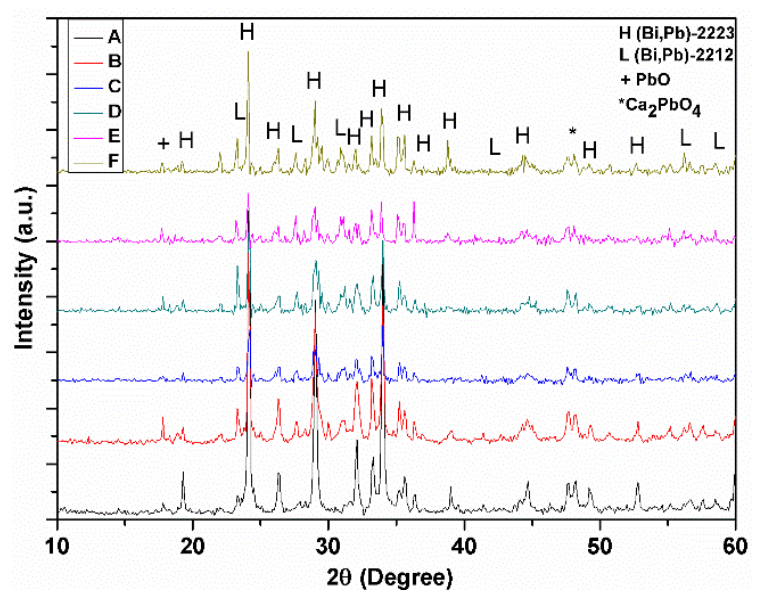

Figure 2. X-ray powder diffraction patterns of $(\mathrm{BiPb})_{2} \mathrm{~W}_{\mathrm{x}} \mathrm{Sr}_{2} \mathrm{Ca}_{3} \mathrm{Cu}_{4-\mathrm{y}} \mathrm{Mo}_{\mathrm{y}} \mathrm{O}_{12+\&} \quad$ superconducting samples. (L) Bi-2212 phase,(H) Bi-2223 and (*) $\mathrm{Ca}_{2} \mathrm{PbO}_{4}$ secondary phase.

The Debye-Scherrer equation was used for calculate crystal sizes of the samples [18].

$L_{h k l}=\frac{0.9 \lambda}{\beta \operatorname{Cos} \theta}$

In this equation $\mathrm{L}_{\mathrm{hk}}$; average crystal size, $\lambda$; the wavelength of the $x$-ray source, $\beta$; Full Width Half Maximum, FWHM and $\theta$ is the peak angle. The crystal sizes of the samples are also given in Table 1 . The crystal sizes are inversely proportional to the full width half maximum of the peaks. Narrower peaks come with bigger crystal size. The crystal sizes give information about the crystal structure and the quality of the sample and tabulated Table 1. The particle size 
of superconducting samples was growing with increases amount of the Mo content and sample $\mathrm{F}$ has the biggest crystal size than the others. The unit cell volume of all samples slightly changing with Mo content and the sample E has the biggest value. Increasing crystal sizes would reduce inter granular connections. As a result, the resistance of the sample decreased. These results supported by SEM measurements.

Table 1. $\mathrm{X}$-ray powder diffraction measurement results of the sample series $(\mathrm{BiPb})_{2} \mathrm{~W}_{\mathrm{x}} \mathrm{Sr}_{2} \mathrm{Ca}_{3} \mathrm{Cu}_{4-\mathrm{y}} \mathrm{Moy}_{\mathrm{y}} \mathrm{O}_{12+\&}$.

\begin{tabular}{ccccc}
\hline Samples & $\begin{array}{c}\text { a }=\text { b-axis lattice } \\
\text { parameter }(\boldsymbol{\AA})\end{array}$ & $\begin{array}{c}\text { c-axis lattice } \\
\text { parameter }(\AA)\end{array}$ & $\begin{array}{c}\text { Lhkl average particle } \\
\text { size }(\AA)\end{array}$ & $\begin{array}{c}\text { Unit cell volume } \\
\mathbf{V}\left(\AA^{\mathbf{3}}\right)\end{array}$ \\
\hline $\mathbf{A}$ & 5.40654 & 36.84484 & 759.4 & 1077 \\
$\mathbf{B}$ & 5.48634 & 36.10340 & 829.8 & 1086.7 \\
$\mathbf{C}$ & 5.45666 & 34.83166 & 821.9 & 1037.1 \\
$\mathbf{D}$ & 5.45070 & 34.83507 & 856.9 & 1035 \\
$\mathbf{E}$ & 5.62037 & 35.00581 & 1181.5 & 1105.8 \\
$\mathbf{F}$ & 5.46500 & 34.94191 & 1250.5 & 1043,6 \\
\hline
\end{tabular}

The grain morphologies of superconducting $(\mathrm{BiPb})_{2} \mathrm{~W}_{\mathrm{x}} \mathrm{Sr}_{2} \mathrm{Ca}_{3} \mathrm{Cu}_{4-\mathrm{y}} \mathrm{Mo}_{\mathrm{y}} \mathrm{O}_{12+\&}$ samples were investigated in detail by scanning electron microscopy images, grown at 2000 times and illustrated in Fig. 3. From the analyzed of SEM images, the grain structures of all samples exhibit a layered structure which was characteristic of the BSCCO system. It is seen that for the sample A exhibited the specimen of

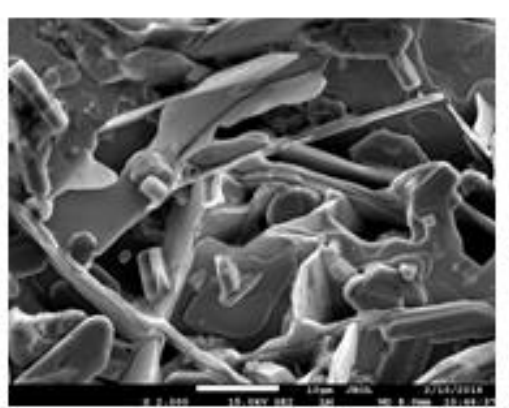

Sample A

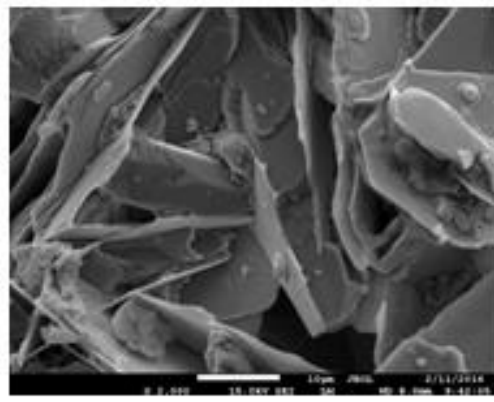

Sample D

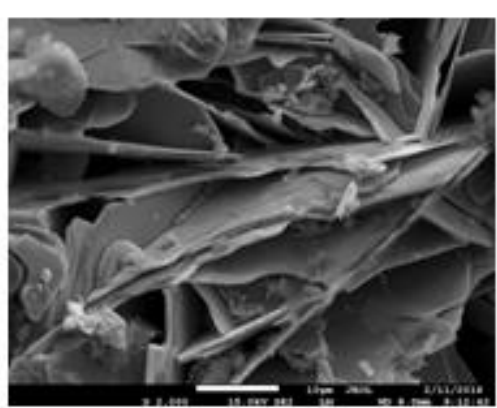

Sample B

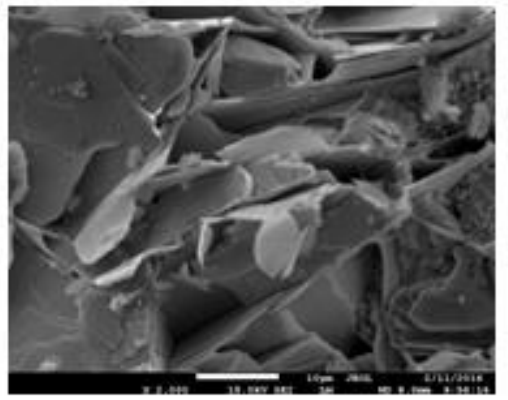

Sample E

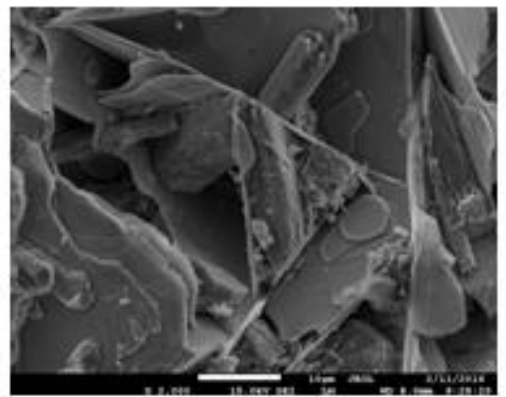

Sample C

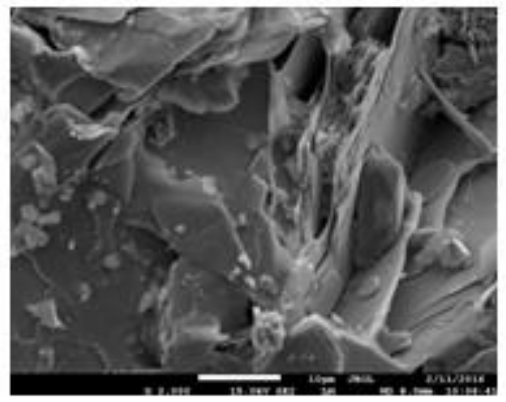

Sample F

Figure 3. SEM images for the samples. 
Fig. 4 shows the variation of the fundamental harmonic AC susceptibility of prepared samples with respect to temperature. In these measurements, the ac magnetic field $\mathrm{H}_{\mathrm{ac}}=$ $1200 \mathrm{~A} / \mathrm{m}$ and frequency $\mathrm{f}=125 \mathrm{~Hz}$ were selected. The measurements were taken at $\mathrm{T}=$ $40-120 \mathrm{~K}$ temperature range. Graphs were obtained by normalizing the maximum and minimum values of the ac susceptibility values of the samples to the range of $[0,-1]$. The in-phase component $\left(\chi^{\prime}\right)$ and the out-ofphase component $(\chi$ ') are also shown in Fig. 4. Transition temperatures (Tc.onset) determined from ac susceptibility measurements of all samples and obtained results were 102.9, 102.1, 101.9, 101.5, 101.4 and $101 \mathrm{~K}$, respectively. From the ac susceptibility curve of all samples exhibits diamagnetic properties under critical transition temperature and it was seen that it had a sharp superconductivity transition at $102.9 \mathrm{~K}$ for sample A.

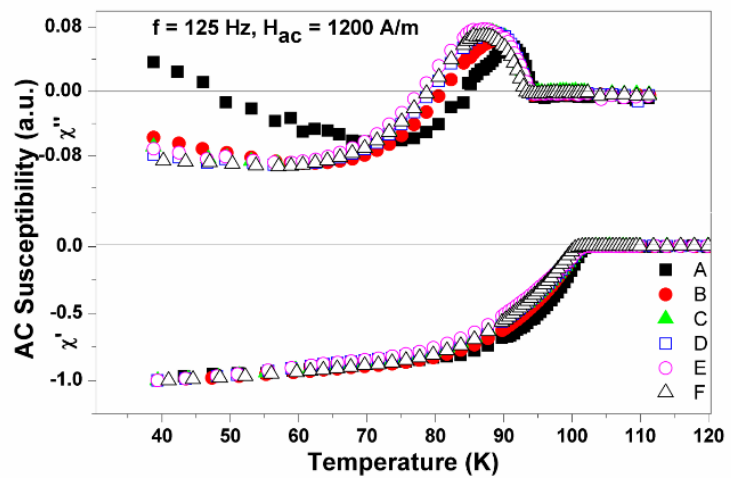

Figure 4. AC susceptibility measurements of the sample series $(\mathrm{BiPb})_{2} \mathrm{~W}_{\mathrm{x}} \mathrm{Sr}_{2} \mathrm{Ca}_{3} \mathrm{Cu}_{4-\mathrm{y}} \mathrm{Moy}_{\mathrm{y}} \mathrm{O}_{12+\& \text {. }}$
Control of the critical transition temperature is believed to depend on the concentration of holes in the $\mathrm{CuO}_{2}$ layers. The Presland method was used in order to calculate p-hole numbers [19].

$\frac{T_{c}}{T_{c, \max }}=1-82.6(p-0.16)^{2}$

The Tc,max value is the highest critical temperature reached and for the $\mathrm{Bi}-2223$ system it is accepted as $110 \mathrm{~K}$ [1]. Tc value is the Tc.offset values of the samples which is given in Table 2. The calculated p-hole numbers are given also Table 2 and values 0.123207, $0.111925,0.103505,0.102539,0.098828$ and 0.102348 , respectively. The calculated results show that the $\mathrm{p}$-values of the superconducting $(\mathrm{BiPb})_{2} \mathrm{~W}_{\mathrm{x}} \mathrm{Sr}_{2} \mathrm{Ca}_{3} \mathrm{Cu}_{4-\mathrm{y}} \mathrm{Moy}_{\mathrm{y}} \mathrm{O} 12+\& \quad$ samples slightly decrease with increasing doping $\mathrm{W}$ and substituted Mo contents. The superconductivity with change is generally found to be $0.05 \leq \mathrm{p} \leq$ 0.27 in High-Tc superconducting systems, [20]. The values of $p$ between 0.05 and 0.27 so $(\mathrm{BiPb})_{2} \mathrm{~W}_{\mathrm{x}} \mathrm{Sr}_{2} \mathrm{Ca}_{3} \mathrm{Cu}_{4-\mathrm{y}} \mathrm{Mo}_{\mathrm{y}} \mathrm{O}_{12+\&}$ samples are optimally doped. From these values doping $\mathrm{W}$ and substituted Mo on superconducting samples change the superconductivity transition temperature. These results are confirmed the research of Turk et al., [13].

Table 2. Tc values, transition width, hole numbers of the sample series $(\mathrm{BiPb})_{2} \mathrm{~W}_{\mathrm{x}} \mathrm{Sr}_{2} \mathrm{Ca}_{3} \mathrm{Cu}_{4-\mathrm{y}} \mathrm{Moy}_{\mathrm{y}} \mathrm{O}_{12+\& \text {. }}$

\begin{tabular}{ccccl}
\hline Samples & $\mathbf{T}_{\mathbf{c}}$ onset $(\mathbf{K})$ & $\mathbf{T}_{\mathbf{c}}$ offset $(\mathbf{K})$ & $\Delta \mathbf{T c}(\mathbf{K})$ & $\mathbf{p}$ (hole numbers) \\
\hline A & 111.5 & 97.7 & 13.8 & 0.123207 \\
B & $109-94,7$ & 89 & 20 & 0.111925 \\
C & $107-91$ & 81 & 26 & 0.103505 \\
D & $106.5-90,8$ & 80 & 26.5 & 0.102539 \\
E & $105.9-88$ & 76 & 29.9 & 0.098828 \\
F & $105.2-89$ & 79.8 & 25.4 & 0.102348 \\
\hline
\end{tabular}

Fig. 5 shows the resistance-temperature curves of $(\mathrm{BiPb})_{2} \mathrm{~W}_{\mathrm{x}} \mathrm{Sr}_{2} \mathrm{Ca}_{3} \mathrm{Cu}_{4-\mathrm{y}} \mathrm{MoyO}_{12+\&}$ superconducting samples. The critical temperature
Tc.onset and Tc.offset values determined from the resistance-temperature curves are given in Table 2. In the R-T curve of the samples, there 
are two Tc.onset transition temperatures except sample A, which are noteworthy. The states observed in the B , C, D, E and F samples are both the sign of the two-valence phase Bi-2223 and $\mathrm{Bi}$-2212. With increasing Mo concentration, the $\mathrm{Bi}-2223$ phase is reduced and thus almost only the $\mathrm{Bi}-2212$ phase is available for all samples. In this case, among the superconducting particles in the samples, weak bonds arise due to non-superconducting phases, low added phases, or the presence of porosity between the particles because of these the superconductivity transition temperature (Tc.onset) is $5-8 \mathrm{~K}$ higher than the transition temperature Tc.onset obtained from the susceptibility measurements (AC). Tc.onset and Tc.offset temperature values of the samples both decreased with the increasing of Mo content, and the transition range to superconductivity $\Delta \mathrm{T}$ values tabulated in Table 2 , increased steadily. The increase in the transition interval reflects the weakness of inter granular link. All samples also show metallic properties up to the starting temperature of the superconducting state transition.

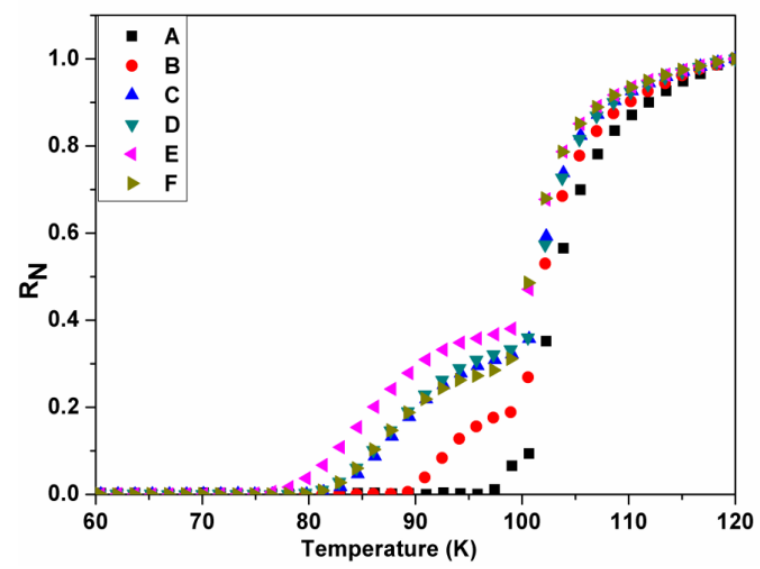

Figure 5. Resistivity measurement vs. temperature for all samples.

\section{CONCLUSION}

In summary, the superconducting $(\mathrm{BiPb})_{2} \mathrm{~W}_{\mathrm{x}} \mathrm{Sr}_{2} \mathrm{Ca}_{3} \mathrm{Cu}_{4-\mathrm{y}} \mathrm{Mo}_{\mathrm{y}} \mathrm{O}_{12+\&}$ samples where $\mathrm{x}=0, \mathrm{y}=0 ; \mathrm{x}=0.1, \mathrm{y}=0.0,0.03,0.06,0.09$ and 0.12 , were prepared by the solid-state reaction method. The effects of $\mathrm{W}$ and Mo co doping on the Bi-based system have been investigated by the electrical resistivity (R-T), scanning electron microscopy (SEM), X-ray diffraction (XRD), energy dispersive X-ray spectroscopy (EDX), magnetic hysteresis and differential thermal analysis technique (TGA). According to XRD results, the main phase is $\mathrm{Bi}-2223$ and a small amount of $\mathrm{Ca}_{2} \mathrm{PbO}_{4}$ phase is encountered for sample A. Also Bi-2212 phase, and $\mathrm{Ca}_{2} \mathrm{PbO}_{4}, \mathrm{PbO}$ phase were observed for the sample $\mathrm{B}, \mathrm{C}, \mathrm{D}, \mathrm{E}$ and $\mathrm{F}$, respectively. The calculated lattice parameters are in accordance with the literature. The SEM images reveal that the granular structures of the all the samples exhibit a layered structure. It is also seen that the grain orientations are random and there are some gaps between the particles in all the samples. According to AC susceptibility results, it has been found that the critical temperature decreases slightly by the addition of high valence cation ( $\mathrm{W}, \mathrm{Mo})$. It was also observed that the hole concentrations of the samples significantly changed with the amount of doping.

\section{REFERENCES}

[1]. Maeda H., Tanaka Y., Fukutomi, M. A new high-Tc oxide superconductor without a rare earth element. Japanese J., 1988.

[2]. Bednorz J.G., Müller K.A., Perovskitetype oxides -The new approach to highTc superconductivity. Rev. Mod. Phys., 1988.

[3]. Özkurt B., Madre M.A., Sotelo A., Diez J.C., Structural, superconducting and mechanical properties of molybdenum substituted Bi1.8Sr2Ca1.1Cu2.1O y. J. Mater. Sci. Mater. Electron., 24 (2013) 1158-1167.

[4]. Wang Y., Wang C., Feng Q., Li X., Ching, T.W. Fabrication and Experiment of Racetrack HTS Magnet for Stator Field-Excitation HTS Machine. IEEE Trans. Appl. Supercond., 1-1 2017.

[5]. Gundogmus H., Ozcelik B., Sotelo A. Madre, M.A. Effect of Yb-substitution on thermally activated flux creep in the $\mathrm{Bi}$ 2Sr2Ca1Cu2-xYbxOy superconductors. 
J. Mater. Sci. Mater. Electron., 24 (2013) 2568-2575.

[6]. Özçelik B., Gündoğmuş H., Yazıcı, D. Effect of $(\mathrm{Ta} / \mathrm{Nb})$ co-doping on the magnetoresistivity and flux pinning energy of the BPSCCO superconductors. J. Mater. Sci. Mater. Electron., 25 (2014) 2456-2462.

[7]. Ozcelik B., Altın S., Yakıncı M. Effect of Vanadium-Titanium Co-doping on the BPSCCO Superconductor. Supercond. Nov. Magn., 2011.

[8]. Sotelo A., Madre M.A., Diez J.C., Rasekh S., Angurel L.A., Martinez E. The influence of $\mathrm{Pb}$ and $\mathrm{Ag}$ doping on the $\mathrm{Jc}(\mathrm{H}, \mathrm{T})$ dependence and the mechanical properties of $\mathrm{Bi}-2212$ textured rods. Supercond. Sci. Technol. 22 (2009) 34012.

[9]. Kalsi S.S. High-Temperature Superconducting Transformers. Wiley Encyclopedia of Electrical and Electronics Engineering., John Wiley \& Sons, Inc., Hoboken, NJ, USA, 2015; pp. $1-25$.

[10]. Das J., Ray R.N. Studies on hunting of hysteresis motor with HTS element on rotor. IEEE 1st International Conference on Power Electronics, Intelligent Control and Energy Systems, 2016; pp. 1-4.

[11]. Angurel, L.A., Díez J.C., De La Fuente G.F., Gimeno F., Lera F., López-Gascón C., Martínez E., Mora M., Navarro R., Sotelo A., Andrés N., Recuero S., Arroyo M.P. Laser technologies applied to the fabrication and characterization of bulk Bi-2212 superconducting materials for power applications. Phys. Status Solidi Appl. Mater. Sci., 203 (2006) 29312937.

[12]. Ozcelik B., Kaya C., Gundogmus H., Sotelo A., Madre M.A. Effect of Ce Substitution on the Magnetoresistivity and Flux Pinning Energy of the $\mathrm{Bi} 2 \mathrm{Sr} 2$ $\mathrm{Ca}_{1-\mathrm{x}} \mathrm{Ce}_{\mathrm{x}} \mathrm{Cu}_{2} \mathrm{O}_{8+\delta}$ Superconductors. J Low Temp Phys., 15 (2013) 2-6.

[13]. Turk N., Gundogmus H., Akyol M., Yakinci Z.D., Ekicibil A., Ozcelik B.
Effect of tungsten (W) substitution on the physical properties of $\mathrm{Bi}-(2223)$ superconductors. J. Supercond. Nov. Magn.,27 (2014) 711-716.

[14]. Hu Q.Y., Liu H.K., Dou S.X. Formation mechanism of high-Tc and critical current in $(\mathrm{Bi}, \mathrm{Pb}) 2 \mathrm{Sr} 2 \mathrm{Ca} 2 \mathrm{Cu} 3 \mathrm{O} 10 / \mathrm{Ag}$ tape. Phys. C Supercond., 250 (1995) 714.

[15]. Gündoğmuş, H. The effect of $\mathrm{Y}$ substitution on $\mathrm{Bi}-2212$ superconductor by sol-gel method. J. Mater. Sci. Mater. Electron., (2017) 1-8.

[16]. Hamadneh I., Agil A., Yahya A.K., Halim S.A. Superconducting properties of bulk Bi1.6Pb0.4Sr2Ca2- xCdxCu3O10 system prepared via conventional solid state and coprecipitation methods. Phys. C Supercond. its Appl., 463-465 (2007) 207-210.

[17]. Aljaafari A., Sedky A., Al-Sawalha A. Impact of $\mathrm{Bi} 2 \mathrm{O} 3$ addition on the normal state properties of $\mathrm{Bi} 3.4 \mathrm{~Pb} 0.3 \mathrm{Sr} 2 \mathrm{Ca} 1.3$ xRExCu2Oy ceramics. J. Phys. Chem. Solids.,69 (2008) 2919-2923.

[18]. Holzwarth U., Gibson N. The Scherrer equation versus the "Debye-Scherrer equation." Nat. Nanotechnol.,6 (2011) 534-534.

[19]. Presland M.R., Tallon J.L., Buckley R.G., Liu R.S., Flower N.E. General trends in oxygen stoichiometry effects on $\mathrm{Tc}$ in $\mathrm{Bi}$ and $\mathrm{Tl}$ superconductors. Phys. C Supercond., 176 (1991) 95-105.

[20]. Altın S., Aksan M.A., Yakıncı M.E., Balc1 Y. The single crystal superconducting Bi-2212 whiskers fabrication and their thermal transport properties. J. Alloys Compd., 502 (2010) $16-23$. 